\title{
TIME SERIES ANALYSIS \\ OF THE POVERTY RATE FOR LOW-EDUCATED PEOPLE IN THE CZECH REPUBLIC, SLOVAKIA AND POLAND OVER THE PERIOD 2005 - 2017
}

\author{
DAGMAR BLATNÁa \\ blatna@vse.cz

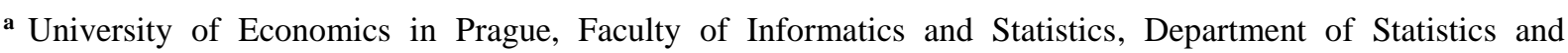 \\ Probability, W. Churchill Sq. 4, Prague, Czech Republic
}

\begin{abstract}
The at-risk-of-poverty rate indicates the proportion of people with disposable income under the poverty threshold. The aim of the present study is to examine the development of the poverty rate indicator in the Czech Republic, Slovakia and Poland over the period 2005 - 2017 in the group of people with no better than lower secondary education. A comparison of the results shows that the lowest poverty rate throughout the period in question is recorded in the Czech Republic. The paper analyses multivariate stationary and non-stationary time series and estimates a regression relationship between the poverty rate and some relevant macroeconomic factors.
\end{abstract}

\section{Key words}

at-risk-of-poverty rate, education level, time series regression analysis, stationarity, non-stationarity

\section{JEL classification}

C32, I32

\section{Introduction}

The goal of the present paper is to statistically examine the development of the poverty rate (PR) indicator for people with low educational background in the Czech Republic, Slovakia and Poland between the years 2005 and 2017. The so-called at-risk-of-poverty rate is one of social exclusion indicators monitoring the achievement of the third headline target of the Europe 2020 Strategy, aimed at people "at risk of poverty or social exclusion". According to the Eurostat definition, the at-risk-of-poverty rate indicates "the share of people with an equivalised disposable income below the at-risk-of-poverty threshold, which is set at 60 per cent of the national median equivalised disposable income after social transfers". The research sample consisted of people who achieved the three lowest levels of education. (The International Standard Classification of Education [ISCED] categorizes them as [0] less than primary, [1] primary and [2] lower secondary.) The study also explores the possibility of applying multivariate time-series regression models, suggesting the relationship between the poverty rate and selected socio-economic factors in the three countries.

\section{Methodology}

Both dependent and explanatory variables being arranged in time series, it is necessary to decide whether the latter ones are stationary or non-stationary prior to using them in the regression analysis. A series is stationary if the mean and autocovariances of the series do not depend on time. The stationary process revers around a constant long-term mean and has a constant variance independent of time. Non-stationary data have a mean, variances and covariances that change over time. Time series of both variables must be of the same order 
integrated rate (the order of integration is the number of differencing operations it takes to make the series stationary). The "classical" regression model can be used when the analysed time series are zero order stationary ones. Applying the unit root tests, it can be concluded that the series are not of the same order, showing no relationship. If tests of a linear combination of two non-stationary time series do not reject the non-stationarity of the nonsystematic component, spurious regression occurs. The relation between the two nonstationary time series exists only if their linear combination is stationary. Then, there is a cointegration relationship considered as a long-term one. For further details see, e.g. Arlt and Arltová (2009), Hušek (2007), Granger et al. (1974), Hendry et al. (1984).

The unit root test is a formal method of testing the stationarity of a series. We applied the Augmented Dickey-Fuller test (ADF) for the verification of the null hypothesis $\mathrm{H}_{0}: \phi_{1}=1$ for non-stationary I(1) time series and $\mathrm{H}_{1}$ : $\left|\phi_{1}\right|=1$ for stationary $\mathrm{I}(0)$ time series.

The ADF test statistic is defined as

$$
t=\frac{\hat{\phi}_{1}-1}{S_{\hat{\phi}}}
$$

where $\hat{\phi}_{1}$ is an estimate of the autoregressive parameter of model $y_{t}=\phi_{1} y_{t-1}+a_{t}, S_{\hat{\phi}_{1}}$ is an estimate of the standard error of $\hat{\phi}_{1}$ and $a_{t}$ is a non-systematic component with white noise characteristics, i.e. the series of uncorrelated random variables $\operatorname{cov}\left(a_{t}, a_{t-k}\right)=0$, probability distribution $N\left(0, \sigma_{a}^{2}\right)$ with zero mean and constant variance $\operatorname{var}\left(a_{t}\right)=\sigma_{a}^{2}$. The test statistic follows the Dickey-Fuller distribution; for critical values, see Dickey and Fuller (1979), for further details, e.g. Arlt and Arltová (2009), Caner and Kilian (2001), Dickey and Fuller (1979, 1981), Elliot et al. (1996) and Phillips (1987).

Validation of the calculated regression model is performed using diagnostic tests of the non-systematic component. To verify the normality, the Jarque-Bera test is carried out. This is a goodness-of-fit test of whether the sample data show the skewness and kurtosis matching a normal distribution; the null hypothesis is a joint one assuming that both the skewness and excess kurtosis are zero. The Jarque-Bera statistic has a $\chi^{2}$ distribution with two degrees of freedom under the null hypothesis of normally distributed errors; see, e.g. Jarque and Bera, 1980. Testing for autocorrelation in regression model errors, Breusch-Godfrey Serial Correlation LM test was conducted with the null hypothesis that there is no serial correlation of any order up to p; cf. Breusch and Godfrey (1986). Autoregressive conditional homoskedasticity in the residuals was verified by ARCH(1) LM test; see Engle (1982).

\section{The at-risk-of-poverty rate (PR) indicator development analysis}

The analysis is based on 2005 - 2017 data for the Czech Republic, Poland and Slovakia, adopted (along with necessary definitions) through the Eurostat database drawn from the EUStatistics on Income and Living Conditions survey (EU-SILC). Statistical calculations were done using EViews 9, Statgraphics and Excel software packages.

There are differences in the development of the at-risk-of-poverty rate indicator between the Czech Republic (PR_C), Poland (PR_P) and Slovakia (PR_S) over the period 2005 2017. As is obvious from Figure 1, the poverty rate of low-educated people was increasing steadily in Slovakia throughout the analysed period. Peaking in 2014, this increase is largely attributed to the economic crisis and the following recession. Poland also shows a general upward trend with a dip in 2013. In the Czech Republic, on the other hand, the impact of the economic downturn on PR indicator was hardly visible. Having held steady at around the level of 17 per cent, the indicator hit a low in 2012 - 2013. Then, it was rising markedly until 2016 when it started to decrease. 
Figure 1: Poverty rates for people with low-level education in the Czech Republic, Poland and Slovakia in $2005-2017$ (in \%)

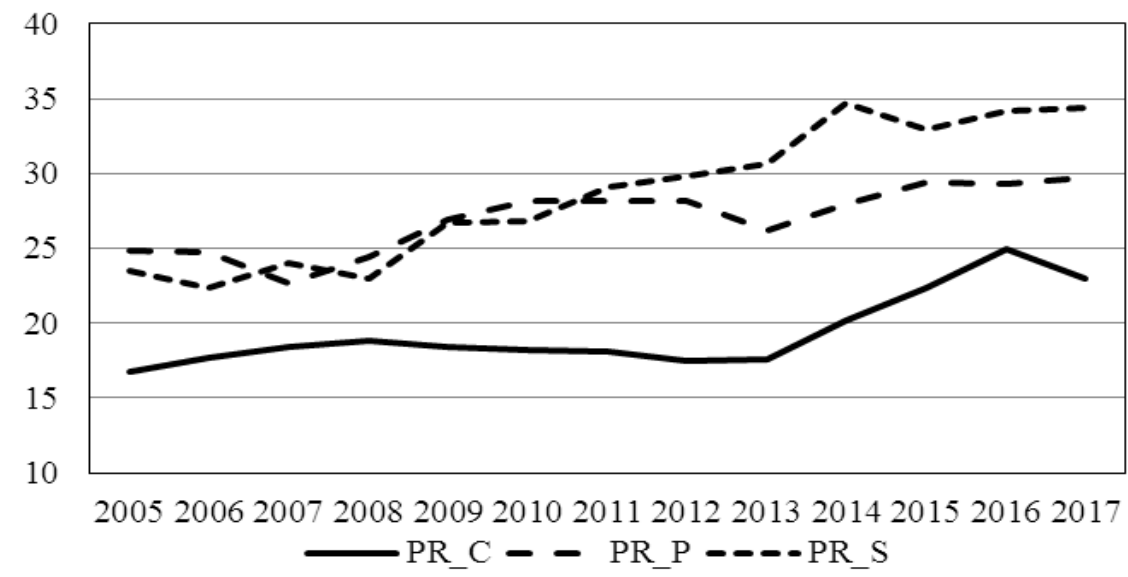

Source: the author based on data from Eurostat.

The values of PR indicator in the Czech Republic were lower than in Slovakia and Poland throughout the monitoring period. The basic characteristics are shown in Table 1. A significant difference between PR levels in the three countries was detected using the nonparametric Kruskall-Wallis test $(\mathrm{KW}=33.8308, \mathrm{p}=4.4053 \mathrm{E}-9)$. (The ANOVA method can not be employed because of heteroskedasticity: Bartlett test $=1.2339, \mathrm{p}=0.0260$.) The difference between poverty rates in Slovakia and Poland is not statistically significant.

Table 1: Basic statistics of PR indicator for people with low level of education

\begin{tabular}{lccc}
\hline \multicolumn{1}{c}{ Statistics } & PR_C & PR_P & PR_S \\
\hline Average & 19.3923 & 26.9769 & 28.6308 \\
Median & 18.4 & 28 & 29.1 \\
Standard deviation & 2.5158 & 2.2301 & 4.5699 \\
Variance & 6.3291 & 4.9735 & 20.8839 \\
Skewness & 0.6296 & -0.8349 & -1.5659 \\
Kurtosis & 1.3002 & -0.5720 & 0.0088 \\
Minimum & 16.8 & 22.7 & 22.4 \\
Maximum & 25 & 29.7 & 34.7 \\
Range & 8.2 & 7.0 & 12.3 \\
Coefficient of variation (\%) & 0.1297 & 0.0827 & 0.1596 \\
Jarque-Bera test of normality / p-value & $2.8413 / 0.2416$ & $1.0851 / 0.5871$ & $1.1451 / 0.5641$ \\
\hline
\end{tabular}

Source: the author.

\section{PR regression analysis and the relationship between selected indicators}

The presented analysis follows the analysis of the at-risk-of-poverty rate in terms of gender and economic activity in the Czech Republic (see Blatná, 2017, 2018). The regression analysis of multivariate time series was conducted, PR indicators representing the dependent variables. The choice of socio-economic indicators used as explanatory variables was limited by the availability and completeness of data for the entire reporting period in all three countries.

The Augmented Dickey-Fuller test identified the stationarity of poverty rate time series in the Czech Republic and Slovakia and the non-stationarity of PR time series in Poland. In Table 2, ADF test values and relevant p-values are presented. 
Table 2: Unit root test of poverty rate for people with low level of education

\begin{tabular}{lcccc}
\hline \multicolumn{1}{c}{ Indicator } & Abbreviation & $\mathrm{t}_{\mathrm{ADF}}$ & $\mathrm{p}$-value & $\begin{array}{c}\text { Stationarity/ } \\
\text { Non-stationarity }\end{array}$ \\
\hline At-risk-of-poverty rate in the CR & PR_C & -4.3417 & 0.0328 & $\mathrm{~S}$ \\
At-risk-of-poverty rate in Poland & PR_P & -3.0673 & 0.1622 & $\mathrm{~N}$ \\
At-risk-of-poverty rate in Slovakia & PR_S & -4.0747 & 0.0375 & $\mathrm{~S}$ \\
\hline
\end{tabular}

Source: the author.

\subsection{PR regression analysis and selected indicators' relationship for the Czech Republic}

The Augmented Dickey-Fuller test identified stationary and non-stationary time series, respectively, of selected indicators employed as explanatory variables for the analysis of the poverty rate of people with a low education level in the Czech Republic (PR_C). ADF test values and relevant $\mathrm{p}$-values are provided in Table 3.

Table 3: Unit root test of selected indicators for the Czech Republic

\begin{tabular}{lcccc}
\hline \multicolumn{1}{c}{ Indicator } & Abbreviation & $\mathrm{t}_{\text {ADF }}$ & p-value & $\begin{array}{c}\text { Stationarity/ } \\
\text { Non-stationarity }\end{array}$ \\
\hline Real GDP per capita growth rate & GDPG_C & -1.9848 & 0.0460 & $\mathrm{~S}$ \\
Inflation rate (HICP) & IR_C & -7.1010 & 0.0014 & $\mathrm{~S}$ \\
Employment rate & ER_C & 1.0098 & 0.9049 & $\mathrm{~N}$ \\
Unemployment rate & UR_C & -1.4743 & 0.1256 & $\mathrm{~N}$ \\
Long-term unemployment rate & LUR_C & -1.9929 & 0.0482 & $\mathrm{~S}$ \\
Unemployment rate by education & UR_02_C & -0.9872 & 0.2711 & $\mathrm{~N}$ \\
Employment growth & EG_C & -1.7847 & 0.0716 & $\mathrm{~N}$ \\
Part-time employment rate & PTER_C & -7.7446 & 0.0004 & $\mathrm{~S}$ \\
Social benefits & SB_C & -1.4541 & 0.5210 & $\mathrm{~N}$ \\
Early leavers from education and training & ELE_C & -1.0259 & 0.7070 & $\mathrm{~N}$ \\
Gross household saving rate & HSR_C & -1.5284 & 0.4857 & $\mathrm{~N}$ \\
Households with broadband access & IA_C & -6.4647 & 0.0006 & $\mathrm{~S}$ \\
Individuals regularly using the internet & IUI_C & -3.3715 & 0.0244 & $\mathrm{~S}$ \\
Lifelong learning & LL_C & -1.5884 & 0.4349 & $\mathrm{~N}$ \\
GERD & GERD_C & -3.9023 & 0.0576 & $\mathrm{~N}$ \\
Average salary growth & SG_C & -0.5044 & 0.4762 & $\mathrm{~N}$ \\
Minimum wage growth & MWG_C & -2.8321 & 0.2227 & $\mathrm{~N}$ \\
People living in households with very low work intensity & LWI_C & -3.6671 & 0.0777 & $\mathrm{~N}$ \\
\hline Source: that
\end{tabular}

Source: the author.

Since the time series are to be of the same integrated process type, it can be concluded that there is no relationship between the PR_C and indicators whose time series are nonstationary. Due to the stationarity of dependent variable PR_C, only stationary indicators are included in the regression analysis as explanatory variables. The statistically most appropriate model is presented in this paper. The best regression model included explanatory variables LUR_C and GDPG_C (see Table 4).

Table 4: Regression model PR_C LUR_C + GDPG_C

\begin{tabular}{ccccc}
\hline Variable & Coefficient & Std. error & t-statistic & p-value \\
\hline C & 25.4760 & 1.3746 & 18.5333 & 0.0000 \\
LUR_C & -2.6156 & 0.5202 & -5.0279 & 0.0005 \\
GDPG_C & 0.3303 & 0.1347 & 2.4531 & 0.0241 \\
\hline
\end{tabular}

Source: the author.

The at-risk-of-poverty rate for people with the lowest level of educational attainment in the Czech Republic grows with increasing GDP and declines with a rising long-term unemployment rate. The model explains 72.28 per cent of the PR_C time series dynamics, its determination index is 0.7228 , the $F$-test being significant $(F=13.0531, p=0.0016)$. The 
ADF test confirms the stationarity of the non-systematic component $(t=-2.5454, p=0.0164)$. This model is acceptable from the statistical point of view, diagnostic tests (see Table 5). confirming that the non-systematic component has a normal distribution (Jarque-Bera test JB $=1.4803, \mathrm{p}=0.4770)$, is homoscedastic $(\mathrm{ARCH}=0.2290, \mathrm{p}=0.6426)$ and not autocorrelated (Breuch-Godfray LM test $\mathrm{F}=0.7920, \mathrm{p}=0.4865$ ). Because of the stationarity of all variables, the model posits only a short-term relationship. The development of dependent variable PR_C and explanatory variables LUR_C and GDPG_C is plotted in Figure 2.

Figure 2: Development of PR, LUR and GDPG indicators for the Czech Republic, over 2005 $-2017$

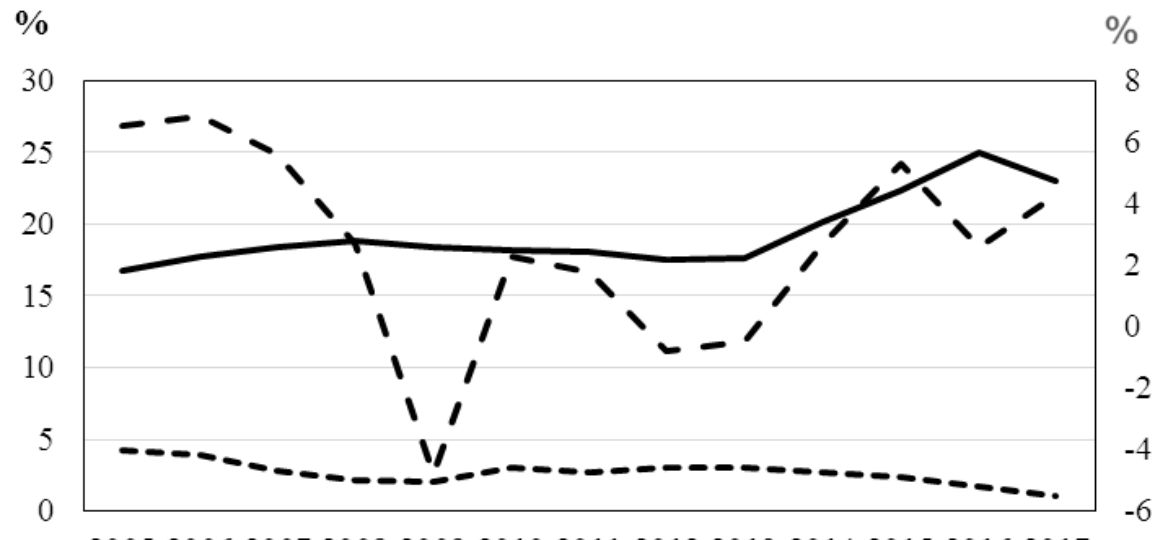

2005200620072008200920102011201220132014201520162017

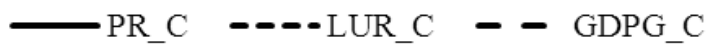

Source: the author based on data from Eurostat.

Table 5: Diagnostic tests of non-systematic component - PR_C LUR_C + GDPG_C

\begin{tabular}{lccc}
\hline \multicolumn{1}{c}{ Test } & Test statistic & Distribution & p-value \\
\hline Breusch-Godfrey serial correlation LM test & 0.7920 & $\mathrm{~F}(2,8)$ & 0.4865 \\
Normality test: Jarque-Bera & 1.4803 & & 0.4770 \\
Heteroskedasticity test: ARCH test & 0.2290 & $\mathrm{~F}(1,10)$ & 0.6426 \\
\hline
\end{tabular}

Source: the author.

\subsection{PR regression analysis and selected indicators' relationship for Poland}

Upon carrying out the unit root test, non-stationarity of the PR_P time series dependent variable was identified $\left(\mathrm{t}_{\mathrm{ADF}}=-1.2258, \mathrm{p}=0.1885\right)$. Since most of the selected explanatory variables of Poland time series are also non-stationary, they were included in the regression analysis.

Several regression models with different combinations of explanatory variables were created within the regression analysis for Poland. Only the two most statistically suitable ones, however, are introduced in this article. The first model containing EG_P (employment growth) and LL_P (lifelong learning) variables is specified in Table 7 below. Due to the nonstationarity of dependent and explanatory variables, non-stationarity of the non-systematic component of their linear combination was tested applying the ADF test. As the test rejects non-stationarity $(\mathrm{t}=-3.3717, \mathrm{p}=0.0029)$, the time series are cointegrated, the model representing a long-term relationship.

The at-risk-of-poverty rate for people with a low educational background in Poland declines with an increasing employment rate and rises with the growth of lifelong learning. The model accounts for 86.26 per cent of time series PR_P dynamics, the F-test providing significant information $(\mathrm{F}=31.2963, \mathrm{p}=0.0001)$. In terms of statistics, this model is acceptable, diagnostic tests proving that the non-systematic component is normally distributed 
(Jarque-Bera test $\mathrm{t}=5.4118, \mathrm{p}=0.0545)$, homoskedastic $(\mathrm{ARCH}=0.1120, \mathrm{p}=0.7448)$ and not autocorrelated (Breuch-Godfray LM test $\mathrm{F}=0.3400, \mathrm{p}=0.7216$ ).

Table 6: Unit root test of selected indicators for Poland

\begin{tabular}{lcccc}
\hline \multicolumn{1}{c}{ Indicator } & Abbreviation & $\mathrm{t}_{\text {ADF }}$ & p-value & $\begin{array}{c}\text { Stationarity/ } \\
\text { Non-stationarity }\end{array}$ \\
\hline Real GDP per capita growth rate & GDPG_P & -0.9671 & 0.2751 & $\mathrm{~N}$ \\
Inflation rate (HICP) & IR_P & -0.9743 & 0.2762 & $\mathrm{~N}$ \\
Employment rate & ER_P & -3.3559 & 0.1096 & $\mathrm{~N}$ \\
Unemployment rate & UR_P & -1.2280 & 0.1721 & $\mathrm{~N}$ \\
Long-term unemployment rate & LTU_P & -3.3959 & 0.0354 & $\mathrm{~S}$ \\
Unemployment rate by education & UR_02_P & -3.0673 & 0.1622 & $\mathrm{~N}$ \\
Employment growth & EG_P & 1.6040 & 0.9621 & $\mathrm{~N}$ \\
Employment rate of low skilled persons & ERL_P & -5.8009 & 0.0010 & $\mathrm{~S}$ \\
Part-time employment rate & PTER_P & -4.1320 & 0.0098 & $\mathrm{~S}$ \\
Social benefits & SB_P & -2.4662 & 0.1480 & $\mathrm{~N}$ \\
Early leavers from education and training & ELE_P & -0.4851 & 0.4841 & $\mathrm{~N}$ \\
Gross households saving rate & HSR_P & -0.5282 & 0.4622 & $\mathrm{~N}$ \\
Households with broadband access & IA_P & -4.1347 & 0.0147 & $\mathrm{~S}$ \\
Individuals regularly using the internet & IUI_P & -5.3354 & 0.0095 & $\mathrm{~S}$ \\
Lifelong learning & LL_P & -2.7723 & 0.2319 & $\mathrm{~N}$ \\
People living in households with very low work intensity & LWI_P & -4.7846 & 0.0035 & $\mathrm{~S}$ \\
\hline Source: the auh
\end{tabular}

Source: the author.

Table 7: Regression model PR_P EG_P + LL_P

\begin{tabular}{ccccc}
\hline Variable & Coefficient & Std. error & t-statistic & p-value \\
\hline C & 40.4393 & 2.2403 & 18.0514 & 0.0000 \\
EG_P & -0.7347 & 0.1396 & -5.2618 & 0.0004 \\
LL_P & -2.8142 & 0.5021 & -5.6043 & 0.0002 \\
\hline
\end{tabular}

Source: the author.

Figure 3: Development of PR, EG and LL indicators for Poland, over 2005 - 2017

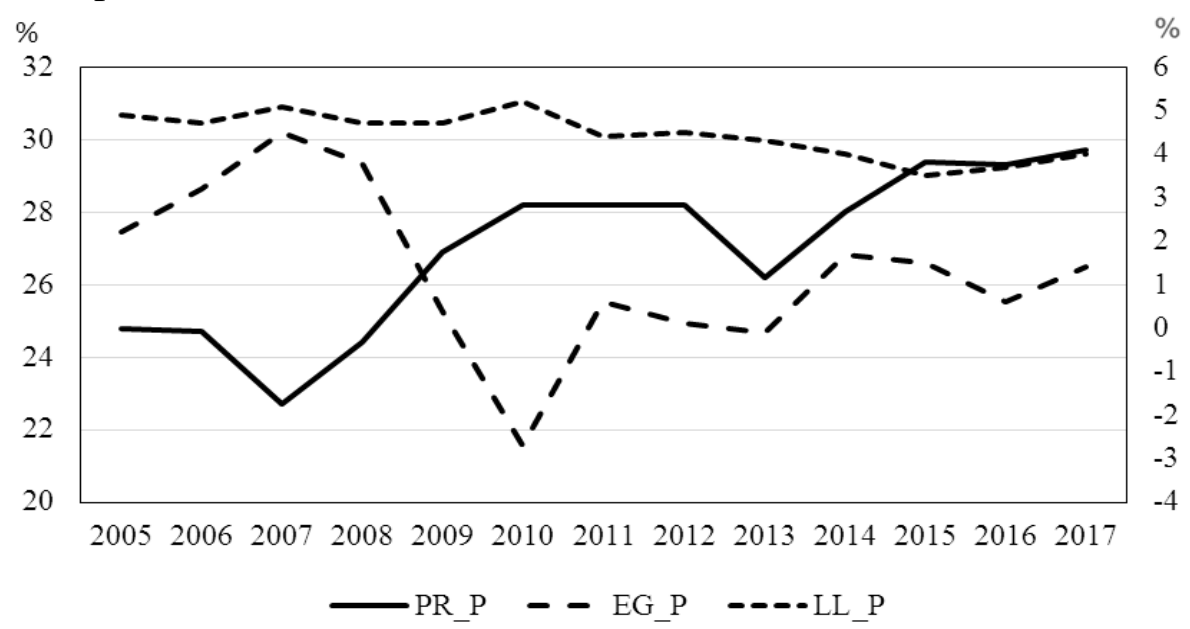

Source: the author based on data from Eurostat.

Another statistically relevant, diagnostically tested regression model is the one with explanatory variables ER_P (employment rate) and UR_02_P (unemployment rate of loweducated people). The development of dependent variable PR_P and ER_P and UR_02_P explanatory variables, respectively, is illustrated in Figure 4.

The ADF test confirms that the non-systematic component $(t=-2.7308, p=0.0113)$ is stationary. This model expresses cointegration, thus also suggesting a long-term relationship. The at-risk-of-poverty rate for low-educated people in Poland increases with overall 
employment growth and with an increasing unemployment rate for people with a low level of education. The model explains 76.60 per cent of time series PR_P dynamics, the F-test being significant $(\mathrm{F}=16.3506, \mathrm{p}=0.0007)$. This model is acceptable from the statistical point of view. For diagnostic tests, see Table 9.

Table 8: Regression model PR_P ER_P + UR_02_P

\begin{tabular}{ccccc}
\hline Variable & Coefficient & Std. error & t-statistic & p-value \\
\hline C & -33.71420 & 11.7387 & -2.8721 & 0.0166 \\
ER_P & 0.8353 & 0.1537 & 5.4324 & 0.0003 \\
UR_02_P & 0.3645 & 0.1239 & 2.9411 & 0.0148 \\
\hline
\end{tabular}

Source: the author.

Table 9: Diagnostic tests of non-systematic component - PR_P ER_P + UR_02_P

\begin{tabular}{lccc}
\hline \multicolumn{1}{c}{ Test } & Test statistic & Distribution & p-value \\
\hline Breusch-Godfrey serial correlation LM test & 2.0393 & $\mathrm{~F}(2,8)$ & 0.1924 \\
Normality test: Jarque-Bera & 0.2784 & & 0.8701 \\
Heteroskedasticity test: ARCH test & 0.0011 & $\mathrm{~F}(1,10)$ & 0.9744 \\
\hline
\end{tabular}

Source: the author.

Figure 4: Development of PR, ER and UR_02 indicators for Poland, over 2005 - 2017

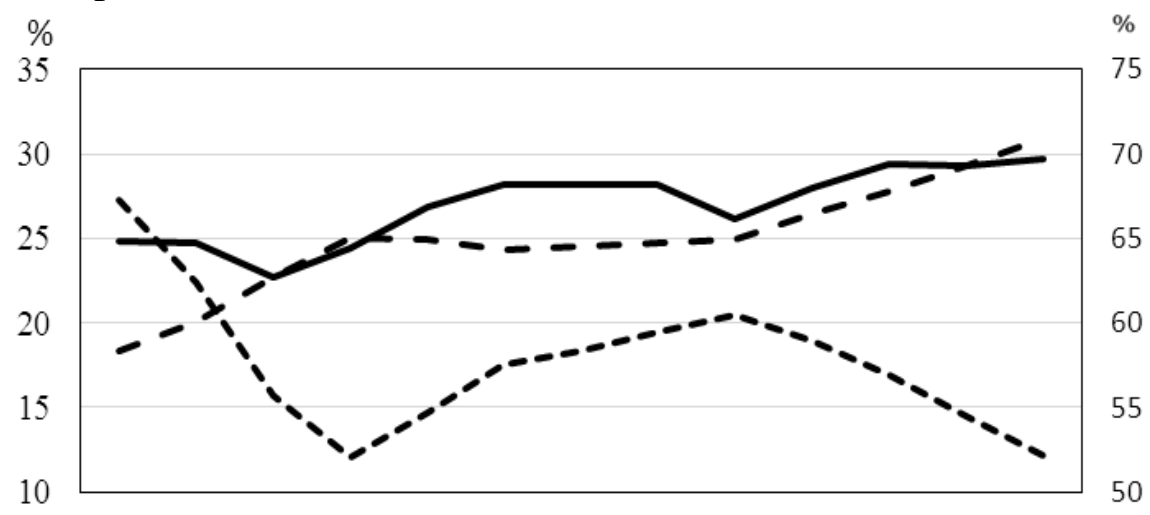

2005200620072008200920102011201220132014201520162017

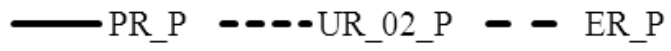

Source: the author based on data from Eurostat.

\subsection{PR regression analysis and selected indicators' relationship for Slovakia}

The ADF test values along with relevant p-values of the indicators selected as explanatory variables for the poverty rate analysis of people with a low level of educational attainment in Slovakia are displayed in Table 11.

The ADF test corroborated the stationarity of PR_S $\left(\mathrm{t}_{\mathrm{ADF}}=-4.0747, \mathrm{p}=0.0375\right)$. Therefore, only stationary time series indicators were included in the regression analysis as explanatory variables, the most appropriate model involving UR_02 (unemployment rate of people with low education level) and SB (social benefits) ones. For the regression model, see Table 10.

Table 10: Regression model PR_S UR_02_S + SB_S

\begin{tabular}{ccccc}
\hline Variable & Coefficient & Std. error & t-statistic & p-value \\
\hline C & 9.2614 & 11.9757 & 0.7733 & 0.4572 \\
UR_02_S & -0.4772 & 0.1358 & -3.5139 & 0.0056 \\
SB_SS & 2.8085 & 0.7245 & 3.8761 & 0.0031 \\
\hline
\end{tabular}

Source: the author. 
The at-risk-of-poverty rate for people with a low level of education in Slovakia decreases with the growth of their unemployment rate and goes up with an increase in social benefits. Since the dependent and independent variables are stationary, the model expresses a shortterm relationship. The model accounts for 77.74 per cent of time series PR_S dynamics, the F-test being also significant $(\mathrm{F}=17.5632, \mathrm{p}=0.0005)$. The ADF test confirms the stationarity of the non-systematic component $(\mathrm{t}=-1.9778, \mathrm{p}=0.0496)$. Table 13 proves that the model is statistically relevant, diagnostic tests corroborating the non-systematic component's normal distribution (Jarque-Bera test $\mathrm{t}=6.4118, \mathrm{p}=0.0405)$, homoskedasticity $(\mathrm{ARCH}=0.1120, \mathrm{p}=$ 0.7448 ) and non-autocorrelation (Breuch-Godfray LM test $\mathrm{F}=0.3400, \mathrm{p}=0.7216$ ). The development of indicators included in the regression model is shown in Figure 5.

Table 11: Unit root test of selected indicators for Slovakia

\begin{tabular}{lcccc}
\hline \multicolumn{1}{c}{ Indicator } & Abbreviation & $\mathrm{t}_{\mathrm{ADF}}$ & $\mathrm{p}$-value & $\begin{array}{c}\text { Stationarity/ } \\
\text { Non-stationarity }\end{array}$ \\
\hline Real GDP per capita growth rate & GDPG_S & -1.8571 & 0.0625 & $\mathrm{~N}$ \\
Inflation rate (HICP) & IR_S & -1.5395 & 0.1120 & $\mathrm{~N}$ \\
Employment rate & ER_S & -1.5676 & 0.7384 & $\mathrm{~N}$ \\
Unemployment rate & UR_S & -1.3925 & 0.1438 & $\mathrm{~N}$ \\
Long-term unemployment rate & LTU_S & -1.6495 & 0.0919 & $\mathrm{~N}$ \\
Unemployment rate by education & UR_02_S & -4.0747 & 0.0375 & $\mathrm{~S}$ \\
Employment growth & RZ_S & -1.5676 & 0.7389 & $\mathrm{~N}$ \\
Employment rate of low skilled persons & ERL_S & -2.1059 & 0.2421 & $\mathrm{~N}$ \\
Part-time employment rate & PTER_S & -4.5454 & 0.0217 & $\mathrm{~S}$ \\
Social benefits & SB_S & -2.2553 & 0.0292 & $\mathrm{~S}$ \\
Early leavers from education and training & ELE_S & 0.2081 & 0.9939 & $\mathrm{~N}$ \\
Gross households saving rate & HSR_S & -2.8397 & 0.0848 & $\mathrm{~N}$ \\
Households with broadband access & IA_S & -4.2659 & 0.0123 & $\mathrm{~S}$ \\
Individuals regularly using the internet & IUI_S & -6.0465 & 0.0044 & $\mathrm{~S}$ \\
Lifelong learning & LL_S & -2.4536 & 0.1590 & $\mathrm{~N}$ \\
People living in households with very low work intensity & PWI_S & -0.5539 & 0.4559 & $\mathrm{~N}$ \\
\hline Source: the aut & & &
\end{tabular}

Source: the author.

Figure 5: Development of PR, SB and UR_02 indicators for Slovakia, over 2005 - 2017

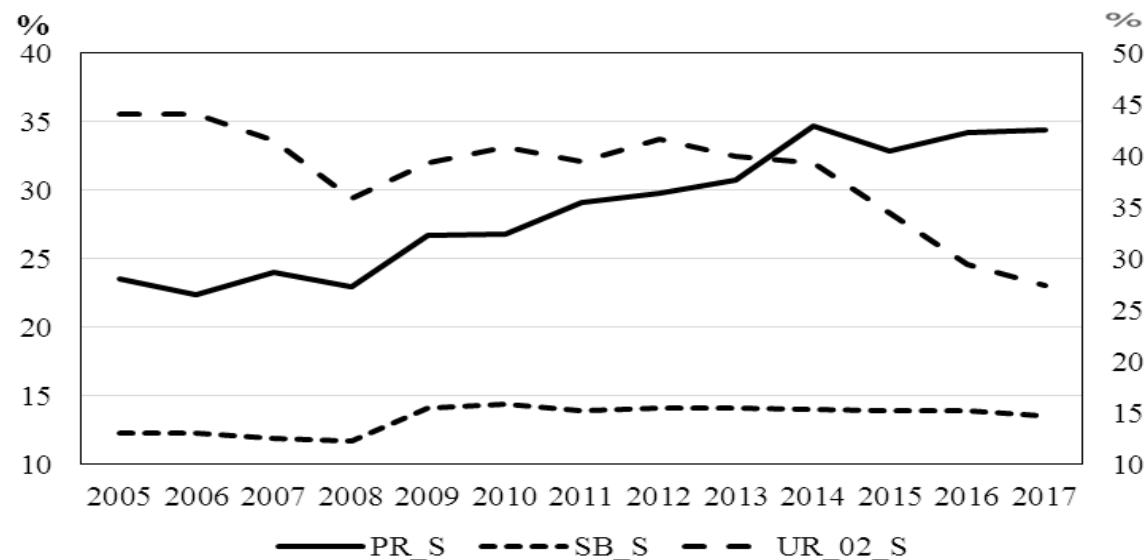

Source: the author based on data from Eurostat.

Table 12: Diagnostic tests of non-systematic component - PR_S UR_02_S + SB_S

\begin{tabular}{lccc}
\hline \multicolumn{1}{c}{ Test } & Test statistic & Distribution & p-value \\
\hline Breusch-Godfrey serial correlation LM test & 1.5096 & F $(2,8)$ & 0.2778 \\
Normality test: Jarque-Bera & 0.3468 & & 0.8408 \\
Heteroskedasticity test: ARCH test & 0.0123 & F $(1,10)$ & 0.9140 \\
\hline
\end{tabular}

Source: the author. 


\section{Conclusion}

The aim of the present paper was to statistically examine the development of the at-risk-ofpoverty rate (PR) indicator for people with low educational background in the Czech Republic, Slovakia and Poland between the years 2005 and 2017. Another objective was to explore the application of multidimensional time series methodology in analyzing the relationship between poverty rates and selected socio-economic factors in these countries.

The most widely accepted definition of the at-risk-of-poverty rate reads that it is "the share of people with an equivalised disposable income below the at-risk-of-poverty threshold, which is set at $60 \%$ of the national median equivalised disposable income after social transfers". The present paper narrows the research sample to people with the lowest educational attainment (the three lowest levels according to the ISCED classification) in the Czech Republic, Poland and Slovakia, the PR indicator being examined between the years 2005 and 2017.

The development of the at-risk-of-poverty rate in the three countries (PR_C, PR_P and PR_S, respectively) is different. In Slovakia and Poland, the trends in PR generally reflected on the post-2008 recession. In the Czech Republic, on the other hand, no or only minimal impact of the global economic downturn on the poverty rate was observed, PR values being considerably lower than in the other two countries throughout the reporting period. The difference between PR levels in Slovakia and Poland is not statistically significant. The Augmented Dickey-Fuller test identified that Czech and Slovak poverty rate time series are stationary, while Polish ones non-stationary.

Applying multivariate time series methodology-based approach several regression models with different combinations of explanatory variables were created. The choice of indicators used as explanatory variables was limited by the availability and completeness of data for the entire reporting period in all three analyzed countries.

For each country, only the most statistically valid regression model has been presented, diagnostic tests having confirmed the normality, homoskedasticity and non-autocorrelation of the non-systematic component. The regression model calculation was dependent on the type of stationarity or non-stationarity of variables, the present models for the Czech Republic and Slovakia, contrary to that for Poland, representing short-term and long-term relationships, respectively.

The at-risk-of-poverty rate for people with the lowest level of educational attainment in the Czech Republic grows with increasing GDP and declines with a rising long-term unemployment rate. With higher GDP growth and lower long-term unemployment, disposable equalised income increases and hence increases the at-risk-poverty threshold, resulting in an increase in the proportion of low-educated people below this threshold. Because of the stationarity of all variables, the model posits only a short-term relationship.

In Poland the at-risk-of-poverty rate for people with a low educational background declines with an increasing employment rate and rises with the growth of lifelong learning. According to the second model for Poland, the at-risk-of-poverty rate for low-educated people increases with overall employment growth and with an increasing unemployment rate for people with a low level of education. These models express cointegration, thus also suggesting a long-term relationship.

The at-risk-of-poverty rate for people with a low level of education in Slovakia decreases with the growth of unemployment rate of low-educated people and goes up with an increase in social benefits. Because the disposable equivalent income depends not only on the size but also on the composition of household (number of adults and children), therefore social benefits may increase the at-risk-poverty threshold and significantly affect the level of the at- 
risk-of-poverty rate indicator. Since the dependent and independent variables in regression model are stationary, the model expresses only a short-term relationship.

In the following research the at-risk-of-poverty rate indicator for other groups of people in terms of education will be analyzed and some more complicated statistical approaches in analysis of multivariate non-stationary time series will be studied.

\section{Acknowledgment}

The paper was institutionally supported by the long-term research scheme of the Faculty of Informatics and Statistics of the University of Economics in Prague.

\section{References}

[1] Arlt, J., Arltová, M. 2009. Ekonomické časové řady. Praha : Professional Publishing, 2009. ISBN 978-80-247-1319-9.

[2] Blatná, D. 2017. Míra rizika chudoby v České republice z hlediska pohlaví. Praha : Oeconomica, 2017. ISBN 978-80-245-2238-8.

[3] Blatná, D. 2018. Analýza vztahu miry rizika chudoby, ekonomické activity a vybraných socioekonomických ukazatelů v ČR v období 2005 - 2016. Praha : SEHS, Ambis, 2018. ISSN 1804-6797.

[4] Breusch, T., Goldfrey, L.G. 1986. Data transformation tests. In Economic Journal, 1986, vol. 96 , pp. 47-58.

[5] Caner, M., Kilian, L. 2001. Size distortions of tests of the null hypothesis of stationarity: Evidence and implications for the PPP debate. In Journal of International Money and Finance, 2001, vol. 20, pp. 639-657.

[6] Dickey, D., Fuller, W. 1979. Distribution of the estimators for autoregressive time series with a unit root. In Journal of the American Statistical Association, 1979, vol. 74, p. 427443.

[7] Dickey, D., Fuller, W. 1981. Likelihood ratio statistics for autoregressive time series with a unit root. In Econometrica, 1981, vol. 49, pp. 1057-1072.

[8] Elliot, G., Rothenberg, J., Stock, J. H. 1996. Efficient tests for an autoregressive unit root. In Econometrica, 1996, vol. 64, pp. 813-836.

[9] Engle, R. F. 1982. Autoregressive conditional heteroskedasticity with estimates of the variance of United Kingdom inflation. In Econometrica, 1982, vol. 50, pp. 987-1007.

[10] Granger, C. W. J., Newbold, P. 1974. Spurious regression in econometrics. In Journal of Econometrics, 1974, vol. 2, iss. 2, pp. 111-120.

[11]Hendry, D., Pagan, A., Sargan, J. 1984. Dynamic specifications. In Griliches, Z., Intriligator, M. (eds.). Handbook of Econometrics. Amsterdam : North Holland, 1984. ISBN 9780444861863.

[12]Hušek, R. 2007. Ekonometrická analýza. Praha : Oeconomica, 2007. ISBN 978-80-2451300-3.

[13]Jarque, C., Bera, A. 1980. Efficient tests for normality, heteroscedasticity, and serial independence of regression residuals. In Economics Letters, 1980, vol. 6, pp. 255-259.

[14]Phillips, P. C. B. 1987. Time series regression with a unit root. In Econometrica, 1987, vol. 55, pp. 277-301. 